\title{
Chemical composition of the leaves of tea bush (Ocimum gratissium L.)
}

\author{
E. I. Adeyeye ${ }^{1 *}$ and M. A. Oyarekua ${ }^{2}$ \\ ${ }^{1}$ Department of Chemistry (Analytical Unit), Ekiti State University, PMB 5363, Ado-Ekiti, Nigeria. \\ ${ }^{2}$ Department of Microbiology, Federal University Oye, P.M.B. 363, Oye-Ekiti, Nigeria.
}

\begin{abstract}
Tea bush leaves are important in the preparation of soups. Crude fat was $5.20 \mathrm{~g} / 100 \mathrm{~g}$. High value results $(\mathrm{g} / 100 \mathrm{~g})$ : protein (28.9), carbohydrate (36.2), ash (9.40), fibre (14.1); fatty acid (4.16g/100g) with energy value (154kJ/100g). High major minerals were: Ca, Mg, K and P, high trace minerals were: $\mathrm{Fe}, \mathrm{Cu}, \mathrm{Mn}$ and $\mathrm{Zn}$. Mineral ratios within nutritional standards: $\mathrm{Na} / \mathrm{K}, \mathrm{Ca} / \mathrm{P}$ and $[\mathrm{K} /(\mathrm{Ca}+\mathrm{Mg})]$. In amino acid composition, highest concentrated amino acid was Glu $(11.0 \mathrm{~g} / 100 \mathrm{~g})$, second was Leu $(7.65 \mathrm{~g} / 100 \mathrm{~g})$, total amino acid (87.2g/100g). Essential amino acid (with His) was 42.5g/100g (48.7\%). Quality parameters obtained in the results: Leu/Ile (1.59), \% Cys/TSAA (42.3), P-PER (2.49) and EAAI (1.18). On quality criteria, Lys was limiting in the three criteria used. Fatty acid had values of SFA (30.9\%), MUFA (5.60\%), PUFA (63.5\%), PUFA/SFA (2.06), n-6/n-3 (1.52), EPA/DHA (1.39). Total phospholipids (44.1mg/100g) with phosphatidylcholine (15.9), phosphatidylinostitol (14.9) predominating. Cholesterol was $0.00 \mathrm{mg} / 100 \mathrm{~g}$, sitosterol was $26.3 \mathrm{mg} / 100 \mathrm{~g}(61.5 \%)$.
\end{abstract}

Keywords: Tea bush; Chemical compositions; Nutritional standard

\section{Introduction}

The green vegetable has long been recognized (Byers, 1961; Oke, 1973) as the cheapest and most abundant potential source of protein because of its ability to synthesize amino acids from a wide range of virtually unlimited and readily available primary materials such as sunlight, water, carbon dioxide, atmospheric nitrogen (as in legumes). Available literature clearly indicates that apart from lower methionine content, the amino acid profile from most leaf species compares favourably with those of soya bean, meat, fish, egg, and generally, surpasses FAO essential amino acid pattern (Eggum, 1970; Babeau, 1989).

The tea bush (Eng.) is called Ocimum gratissimum L. (1753), a Lamiaceae. Nigerian local names (Yor.) are: Efinrin, Efirin, Efirin ibile, Efinrin ibile (Hutchinson et al., 1963; Gbile, 1984). The shrub is up to $1.3 \mathrm{~m}$ in height and the stem is sub-glabrous; usually occurring around villages. As regard the origin, there is controversy as some authorities claimed Africa whereas some mentioned Asia but of ancient introduction to Africa (Hutchinson et al., 1963). Both fresh and dried leaves are used as a flavouring herb (Tindall, 1986). Therapeutically, entire plant is used in the treatment of parasitosis,diarrhea, dysentery, epistaxis, convulsions, fever and dermatosis (Akinadewo, 2001); hence the name fever plant (Tindall, 1986). Kochhar (Kochhar, 1986) had discussed the chemistry of tea leaves particularly the Assam variety and the China variety. Since tea bush leaves are used as flavouring herb in Nigeria, there is need to be aware of the nutritional composition of such leaves; no literature is available for such information. The major aim of this work therefore was to report the analysis of tea bush found in Nigeria for the composition of proximate, minerals, amino acids, fatty acid methyl esters, phospholipids and phytosterols in the leaves. We hope this information will also be available to improve Food Composition Table.

\section{Materials and methods}

\section{Sampling and sample treatment}

Tea bush leaves were obtained at Ifaki Ekiti (a place very close to the Ekiti State University) and were identified at the Herbarium unit of the Department of Plant Science of the same University. The leaf samples were oven dried at low temperature until constant weight and ground into uniform powder using a laboratory blender. The blended sample was kept in plastic rubbers in the laboratory refrigerator pending analysis.

\section{Proximate composition analysis}

The leaf sample was analysed for proximate composition (moisture, ether extract, crude fibre and ash) (Anonymous, 2006).

\footnotetext{
*Corresponding author: E-mail: eiadeyeye@yahoo.com
} 
Nitrogen was determined by the micro-Kjeldahl method (Pearson, 1976) and the percentage of nitrogen was converted to crude protein by multiplying by 6.25 . Both soluble carbohydrate and organic matter were determined by differences. The calorific values were obtained by multiplying the carbohydrate, protein and crude fat by the Atwater factors of 17, 16 and 37 respectively (Kilgour, 1987). The crude fat was converted into fatty acid by multiplying with a conversion factor of 0.80 (Greenfield and Southgate, 2003). All the proximate values were reported in $g / 100 \mathrm{~g}$ sample with the exception of energy. Determinations were in duplicate. The utilizable energy due to protein (UEDP \%) for the sample was calculated.

\section{Mineral analysis}

The minerals were analysed from solutions obtained by first dry ashing the samples at $550^{\circ} \mathrm{C}$. The $\mathrm{Na}$ and $\mathrm{K}$ contents were determined by Flame photometry (Jenway Ltd., Dunmow and Essex, UK) and $\mathrm{P}$ by Vanado-molybdate method (Anonymous, 2006). Fe, Cu, Co, Mn, Zn, Pb, Ca, Mg and $\mathrm{Se}$ were determined using atomic absorption spectrophotometer (Buck Scientific, East Norwalk, CT, USA). In the minerals, the following ratios were calculated: $[\mathrm{K} /(\mathrm{Ca}+\mathrm{Mg})]$ in milliequivalent, $\mathrm{Na} / \mathrm{K}, \mathrm{Ca} / \mathrm{P}$ and $\mathrm{Ca} / \mathrm{Mg}$. All chemicals used were of British Drug House (BDH) analytical grade.

\section{Determination of amino acid profile}

\section{Defatting}

$2.0 \mathrm{~g}$ of the sample was weighed into extraction thimble and the fat was extracted with chloroform/methanol $(2: 1 \mathrm{v} / \mathrm{v}$ mixture) using Soxhlet extraction apparatus as described by (Anonymous, 2006). The extraction lasted for $5 \mathrm{~h}$.

\section{Hydrolysis of the sample}

About $30 \mathrm{mg}$ of the defatted sample was weighed into glass ampoules. Seven millilitres of $6 \mathrm{MHCl}$ were added and oxygen was expelled by passing nitrogen into the ampoule. (This is to avoid possible oxidation of some amino acids during hydrolysis.) The glass ampoule was then sealed with Bunsen burner flame and put in an oven pre-set at $105 \pm 5^{\circ} \mathrm{C}$ for $22 \mathrm{~h}$. The ampoule was allowed to cool before broken open at the tip and the content was filtered to remove the humins. The filtrate was then evaporated to dryness at $40^{\circ} \mathrm{C}$ under vacuum in a rotary evaporator. The residue was dissolved with $5 \mathrm{ml}$ acetate buffer $(\mathrm{pH} 2.0)$ and stored in plastic specimen bottles which were kept in the freezer.
Loading of the hydrolysate into the TSM analyser/amino acid analysis

The amount loaded was between 5 to 10 microlitres. This was dispensed into the cartridge of the analyser. The amino acid analysis was done by ion-exchange chromatography (Spackman et al., 1958) using a Technicon Squential Multisample Amino Acid Analyser (Technicon Instruments Corporation, New York, USA).

\section{Estimation of isoelectric point (pI)}

The theoretical estimation of isoelectric point (pI) was determined using the equation of Olaofe and Akintayo (2000) and information provided by Finar (Finar, 1975):

$$
\mathbf{I P m}=\sum_{i=1}^{n} I_{i} X_{i}
$$

where IPm is the isoelectric point of the $\mathrm{i}^{\text {th }}$ amino acid in the mixture and $\mathrm{Xi}$ is the mass or mole fraction of the $\mathrm{i}^{\text {th }}$ amino acid in the mixture.

\section{Estimation of predicted protein efficiency ratio (P-PER)}

The predicted protein efficiency ratio (P-PER) was estimated by using the equation given by:

$$
\text { P-PER }=-0.468+0.454 \text { (Leu) }-0.105 \text { (Tyr) (Alsmeyer et al.,1974). }
$$

\section{Estimation of dietary protein quality}

The amino acid scores were calculated using three different procedures:

- The total amino acids scores were calculated based on the whole hen's egg amino acid profile (Paul and Southgate, 1978).

- The essential amino acids scores were calculated using the formula (provisional amino acid scoring pattern) (Anonymous, 1973): Amino acid score $=$ Amount of amino acid per test protein $[\mathrm{mg} / \mathrm{g}] /$ Amount of amino acid per protein in reference $[\mathrm{mg} / \mathrm{g}]$.

- The essential amino acids scores (including His) based on pre-school child suggested requirement (Anonymous, 1985).

\section{Essential amino acid index (EAAI)}

The essential amino acid index (EAAI) was calculated by using the ratio of test protein to the reference protein for each eight essential amino acids plus histidine in the equation (Steinke et al., 1980): 


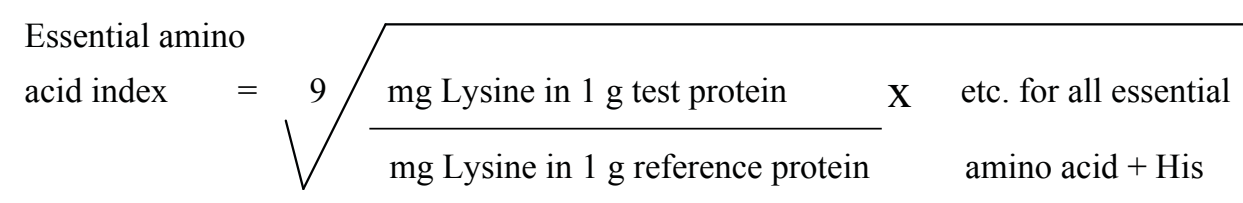

\section{Leu/Ile ratio}

The leucine/isoleucine ratio, their difference and their percentage difference were also calculated.

\section{Extraction of lipid for fatty acid analysis}

About $0.25 \mathrm{~g}$ of the sample was weighed into the extraction thimble. $200 \mathrm{ml}$ of petroleum ether $\left(40-60^{\circ} \mathrm{C}\right.$ boiling range $)$ was measured and then added to the dried $250 \mathrm{ml}$ capacity flask. The covered porous thimble with the sample was placed in the condenser of the Soxhlet extractor arrangement that had been assembled (Anonymous, 2006). The lipid was extracted for $5 \mathrm{~h}$. The extraction flask with the crude fat was oven dried at $105^{\circ} \mathrm{C}$ for $1 \mathrm{~h}$. The flask containing the dried oil was cooled in the desiccator and the weight of the cooled flask with the dried oil was taken.

\section{Preparation of methyl esters and analysis}

$50 \mathrm{mg}$ of the extracted oil was saponified for $5 \mathrm{~min}$ at $95^{\circ} \mathrm{C}$ with $3.4 \mathrm{ml}$ of $0.5 \mathrm{M} \mathrm{KOH}$ in dry methanol. The mixture was neutralized by $0.7 \mathrm{M} \mathrm{HCI} .3 \mathrm{ml}$ of $14 \%$ boron triflouride in methanol was added (Anonymous, 2006). The mixture was heated for $5 \mathrm{~min}$ at $90^{\circ} \mathrm{C}$ to achieve complete methylation process. The fatty acid methyl esters were thrice extracted from the mixture with redistilled $\mathrm{n}$-hexane. The content was concentrated to $1 \mathrm{ml}$ for analysis and $1 \mu \mathrm{l}$ was injected into the injection pot of the GC. The fatty acid methyl esters were analysed using an HP 5890 powered with HP gas chromatograph (HP 5890 powered with HP ChemStation rev.A09.01) (1206) software [GMI, Inc, Minnesota,USA] fitted with a flame ionization detector. Nitrogen was the carrier gas with a flow rate of $20-60 \mathrm{ml} / \mathrm{min}$. The injection temperature was $250^{\circ} \mathrm{C}$ whilst the detector temperature was $320^{\circ} \mathrm{C}$. A capillary column $(30 \mathrm{~m} \times 0.25 \mathrm{~mm})$ packed with a polar compound (HP INNOWAX) with a diameter $(0.25 \mu \mathrm{m})$

was used to separate the esters. Split injection type was used having a split ratio of 20:1. The peaks were identified by comparison with standard fatty acid methyl esters.

Calculation of fatty acid as food per $100 \mathrm{~g}$ and the energy contribution per $100 \mathrm{~g}$ in sample

At the data source and reference database levels, values for individual fatty acids are usually expressed as percentages of total fatty acids. At the user database level, values per $100 \mathrm{~g}$ of food are required. A conversion factor derived from the proportion of the total lipid present as fatty acids is required for converting the percentages of total fatty acids to fatty acids per $100 \mathrm{~g}$ of food. Total lipid level (crude fat) was multiplied by conversion factor as follows: sample $(5.20 \mathrm{x}$ $0.80=4.16 \mathrm{~g} / 100 \mathrm{~g}$ ) (Anderson, 1976). For fatty acids, precision is best limited to $0.1 \mathrm{~g} / 100 \mathrm{~g}$ of fatty acids (Greenfield and Southgate, 2003). The energy contribution of the fatty acids in the sample was also calculated.

\section{Phytosterol analysis}

Aliquot of the dried oil was added to screw-capped test tubes. The sample was saponified at $95^{\circ} \mathrm{C}$ for $30 \mathrm{~min}$, using $3 \mathrm{ml}$ of $10 \% \mathrm{KOH}$ in ethanol, to which $0.20 \mathrm{ml}$ of benzene was added to ensure miscibility. Deionsed water $(3 \mathrm{ml})$ was added and 2 $\mathrm{ml}$ of hexane was used in extracting the non - saponifiable materials. Three extractions, each with $2 \mathrm{ml}$ of hexane, were carried out for $1 \mathrm{~h}, 30 \mathrm{~min}$ and $30 \mathrm{~min}$ respectively, to achieve complete extraction of the phytosterols. Hexane was concentrated to $1 \mathrm{ml}$ for gas chromatographic analysis.

\section{Phospholipid analysis}

By using a modified method of Raheja and Co-workers (Raheja et al., 1973), 0.01g of the dried oil was added to test tubes. Any remaining solvent was removed by passing a stream of nitrogen gas over the oil. Then $0.40 \mathrm{ml}$ of chloroform was added, followed by addition of $0.10 \mathrm{ml}$ of the chromogenic solution. The tube was heated to $100^{\circ} \mathrm{C}$ in a water bath for $1 \mathrm{~min} 20 \mathrm{sec}$, cooled to room temperature, $4 \mathrm{ml}$ of hexane was added and the tube was shaken gently several times. After separation of the solvent and aqueous layers the hexane layer was recovered and concentrated to $1.0 \mathrm{ml}$ for analysis. Analysis was performed using the gas chromatograph with a polar (HP5) capillary column ( $30 \mathrm{~m} \times 0.25 \mathrm{~mm} \times 0.25 \mu \mathrm{m})$. The oven programme was: initially at $50^{\circ} \mathrm{C}$ ramping at $10^{\circ} \mathrm{C} / \mathrm{min}$ for $20 \mathrm{~min}$, held for $4 \mathrm{~min}$, a second ramping at $15^{\circ} \mathrm{C} / \mathrm{min}$ for $4 \mathrm{~min}$ and held for $5 \mathrm{~min}$. The injection temperature was $250^{\circ} \mathrm{C}$, and the detector temperature was $320^{\circ} \mathrm{C}$. As previously described, a split injection type was used having a split ratio of 20:1. Peaks were identified by comparison with the known standards. 


\section{Results and discussion}

The proximate composition of tea bush is shown in Table I. The following parameters were high $(\mathrm{g} / 100 \mathrm{~g})$ in the sample: crude protein (28.9), available carbohydrate (36.2), total ash (9.40) and crude fibre (14.1). The total energy due to total fatty acid was low at $154 \mathrm{~kJ} / 100 \mathrm{~g}$ whereas total energy from carbohydrate, crude fat and protein was $1270 \mathrm{~kJ} / 100 \mathrm{~g}$ sample whose total individual energy ranged from $192-615 \mathrm{~kJ} / 100 \mathrm{~g}$ or percentage range of $15.1-48.4 \%$. for this purpose. The proximate results in the tea bush were highly comparable with the proximate results in the leaves of Aerva lanata $L$. (another medicinal plant) with values as: ash $(31.2 \%)$, moisture $(6.38 \%)$, crude protein $(22.6 \%)$, crude fat $(6.43 \%)$ and carbohydrate $(26.6 \%)$ (Omoyeni and Adeyeye, 2009). The energy content of the proximate fractions (fat, protein, carbohydrate) ranged as $192-615 \mathrm{~kJ} / 100 \mathrm{~g}$ (or 1.27 MJ, mega Joule) showing the leaves to be good sources of concentrated energy, due to their high protein, carbohydrate but slightly low fat contents. Energy from cereals range from

Table I. Proximate composition of tea bush (g/100g dry weight of sample)

\begin{tabular}{lcccc}
\hline Parameter & Value & Energy value & Percentage energy & UEDP \% \\
\hline Crude fat & 5.20 & 192 & 15.1 & - \\
Crude protein & 28.9 & 462 & 36.4 & 21.8 \\
Carbohydrate & 36.2 & 615 & 38.4 & - \\
Total ash & 9.40 & - & - & - \\
Crude fibre & 14.1 & - & - & - \\
Moisture & 6.20 & - & - & - \\
Organic matter & 90.6 & - & - & - \\
Total energy & - & 1270 & - & - \\
Total fatty acid & 4.16 & 154 & - & - \\
\hline
\end{tabular}

${ }^{+}$Energy value in $\mathrm{kJ} / 100 \mathrm{~g}$ sample; ${ }^{++}$Crude fat $\mathrm{x} 0.80 ; \mathrm{UEDP} \%=$ utilizable energy due to protein per cent.

The sample had low moisture content $(6.20 \mathrm{~g} / 100 \mathrm{~g})$, this is an indication that it would not be liable to microbial spoilage easily. The ash content $(9.40 \mathrm{~g} / 100 \mathrm{~g})$ was moderately high suggesting that the tea bush could probably provide essential, valuable and useful minerals needed for good body development. The high content of crude protein $(28.9 \mathrm{~g} / 100 \mathrm{~g})$ was an indication that the leaves were good sources of protein for humans and could also be utilised as feed stocks for animals. The value here was found to be higher than the one reported for Anisopus mannii (8.4\%) by Aliyu and Co-workers (Aliyu et al., 2009). The leaves were also high in carbohydrate $(36.2 \mathrm{~g} / 100 \mathrm{~g})$ which is a quick source of energy and also needed in the diet to ensure efficient oxidation of fats (Mudambi and Rajagopal, 1983). The value for crude fibre was $14.1 \mathrm{~g} / 100 \mathrm{~g}$ and since it has been found to possess hypocholesterolemic properties (Selvendran et al., 1979), tea bush leaves might be exploited
1.3 -1.6 MJ/100g (Paul and Southgate, 1978). Column 4 of Table I shows the various energy values as contributed by fat, protein and carbohydrate (in percentage levels). Whilst the fat had the least contribution (15.1\%), carbohydrate had the highest contribution (48.4\%). The fat contribution of $15.1 \%$ of total energy was about half of $30 \%$ recommended energy from fat particularly for adults (Davies, 1991); this is useful for people wishing to adopt the guidelines for a healthy diet. In column 5 Table I, we have the utilizable energy due to protein (UEDP\%) for the tea bush (assuming 60\% utilization) with a value of 21.8. This value is higher than the recommended safe level of $8 \%$ for an adult man who requires about $55 \mathrm{~g}$ protein per day with $60 \%$ utilization; this means the protein energy contribution would be more than enough to prevent protein energy malnutrition (PEM) in an adult fed solely on tea bush as a main source of protein. 
Table II. Mineral composition of tea bush (mg/100g dry weight of sample)

\begin{tabular}{llc}
\hline Mineral & Value & Standard \\
\hline $\mathrm{Fe}$ & 10.8 & - \\
$\mathrm{Cu}$ & 1.97 & - \\
$\mathrm{Co}$ & 0.0012 & - \\
$\mathrm{Mn}$ & 2.43 & - \\
$\mathrm{Zn}$ & 6.91 & - \\
$\mathrm{Pb}$ & 0.0007 & - \\
$\mathrm{Ca}$ & 292 & - \\
$\mathrm{Mg}$ & 487 & - \\
$\mathrm{K}$ & 610 & - \\
$\mathrm{Na}$ & 35.4 & - \\
$\mathrm{P}$ & 102 & - \\
$\mathrm{Se}$ & 0.0011 & - \\
$\mathrm{Na} / \mathrm{K}$ & 0.058 & 0.60 \\
$\mathrm{Ca} / \mathrm{P}$ & 2.88 & $\geq 0.5$ \\
{$[\mathrm{~K} /(\mathrm{Ca}+\mathrm{Mg})]$} & 1.57 & $<2.2$ \\
$\mathrm{Ca} / \mathrm{Mg}$ & 0.600 & 1.00 \\
\hline
\end{tabular}

In the mineral composition (Table II), $\mathrm{Mg}, \mathrm{K}, \mathrm{Ca}$ and $\mathrm{P}$ were high major minerals; also, $\mathrm{Fe}, \mathrm{Cu}, \mathrm{Mn}$, and $\mathrm{Zn}$ were high trace minerals and low levels of trace elements were in Co $(0.0012 \mathrm{mg} / 100 \mathrm{~g}), \mathrm{Pb} \quad(0.0007 \mathrm{mg} / 100 \mathrm{~g})$ and $\mathrm{Se}$ $(0.0011 \mathrm{mg} / 100 \mathrm{~g})$. Although $\mathrm{Na}$ is a major mineral in animals it is a minor mineral in many plants as shown in this sample as $35.4 \mathrm{mg} / 100 \mathrm{~g}$. The following mineral quality parameters were within standards: $\mathrm{Na} / \mathrm{K}, \mathrm{Ca} / \mathrm{P},[\mathrm{K} /(\mathrm{Ca}+\mathrm{Mg})]$ whereas $\mathrm{Ca} / \mathrm{Mg}$ was just about half of the standard.

From the present study, it was discovered that tea bush leaves were rich sources of most essential minerals (mg/100g sample): $\mathrm{Na}$ (35.4), K (610), Ca (292), Mg (487), Fe (10.8), P (102), $\mathrm{Zn}$ (6.91), Cu(1.97) and Mn (2.43). For instance, both $\mathrm{Ca}$ and $\mathrm{Mg}$ are chiefly found in the skeleton. Ca helps in forming and maintaining bone, blood clotting and muscle contraction. In addition to its structural role, $\mathrm{Mg}$ also activates enzymatic processes. Na and $\mathrm{K}$ control water equilibrium levels in body tissues and are also involved in the transport of some non-electrolytes. $\mathrm{Zn}$ helps in DNA

synthesis, storage, release and function of insulin and also in the development of sexual organs and bones (Crosby, 1977; Wardlaw and Smith, 2009). Fe is essential for haemoglobin formation and $\mathrm{P}$ is for bone and teeth development, $\mathrm{Mn}$ also activates enzymes involved in the transfer of phosphate and hydroxyl groups as well as some hydrogenation reactions (Champe and Harvey, 1994). The lower level of Na than K agreed with what is required in plants (Sutcliffe and Baker, 1974). $\mathrm{Pb}$ level of $0.0007 \mathrm{mg} / 100 \mathrm{~g}$ could be due to an onset of pollution of the environment. Both $\mathrm{Na}$ and $\mathrm{K}$ are involved in many biochemical activities in the body and the present value of $\mathrm{Na} / \mathrm{K}(0.058)$ was much lower than 0.60 required to avoiding high blood pressure (Nieman et al., 1992). The $\mathrm{Ca} / \mathrm{P}$ was 2.88 putting it within the excellent group (7.79-2.41); this would help to increase the absorption of $\mathrm{Ca}$ in the small intestine. This may help increase the Ca content of bones (Shils and Young, 1988). The $[\mathrm{K} /(\mathrm{Ca}+\mathrm{Mg})]$ obtained was 1.57 milliequivalent. To prevent hypomagnesemia, Marten and Co-workers (Marten and Anderson, 1975) reported that the milliequivalent of $[\mathrm{K} /(\mathrm{Ca}+$ $\mathrm{Mg})$ ] must be less than 2.2; this is the case in this report. The $\mathrm{Ca} / \mathrm{Mg}$ weight ratio was 0.600 , this is below the recommended value of 1.0 (NRC, 1989). Mn was high here unlike what obtains in some animal sources (Adeyeye, 1996). Most of the minerals in this sample are much more concentrated than in Aerva lanata (Omoyeni and Adeyeye, 2009) such as (mg/100g) Ocimum gratissium/Aerva lanata: $\mathrm{Fe}$ (10.8/11.0), Cu (1.97/ND), Mn (2.43/ND), Zn (6.91/44.7), $\mathrm{Ca}(292 / 51.7), \mathrm{Mg}(487 / 41.5), \mathrm{K}(610 / 47.9)$, Na (35.4/39.4) and $\mathrm{P}(102 / 187)$. Also many of the mineral values in the tea bush were better concentrated than in the hull and cotyledon of Irvingia gabonensis (Adeyeye, 2013).

The amino acid composition of the tea bush is shown in Table III. The highest concentrated amino acid was Glu $(11.0 \mathrm{~g} / 100 \mathrm{~g}$ protein), it is a non-essential acidic amino acid and the second highest amino acid was Leu $(7.65 \mathrm{~g} / 100 \mathrm{~g}$ protein), it is an essential amino acid. The value of Met ( $1.88 \mathrm{~g} / 100 \mathrm{~g}$ protein) was close to Cys $(1.38 \mathrm{~g} / 100 \mathrm{~g}$ protein). Trp was the lowest concentrated amino acid $(1.14 \mathrm{~g} / 100 \mathrm{~g}$ protein), it is an essential amino acid. Total amino acid content was $87.2 \mathrm{~g} / 100 \mathrm{~g}$ protein.

Many of both essential and non-essential amino acids were high in concentration. Among the highly concentrated amino acids were: Val, Leu, Phe, Gly, Ala, Pro, Asp, Glu and Arg, each amino acid in this group having value greater than $5.0 \mathrm{~g} / 100 \mathrm{~g}$ protein. On comparison with the leaf of Moringa oleifera (Olaofe et al., 2013) it is noted that tea bush was 
better concentrated in Gly, Ala, Pro, Val, Thr, Ile, Leu, Asp, Lys, Met, Phe and Tyr whereas Ser was of equivalent value (4.33 g/100g protein in both samples) but less in Arg, His, Cys and Glu. It is to be noted that for centuries, people in many countries have used Moringa leaves as traditional medicine for common ailments. On comparison with other three non-conventional leafy vegetables (Adesina and Adeyeye, 2013) the following was observed as compared with Cucurbita maxima, Amaranthus viridis and Basella alba consumed in Nigeria: tea bush was better than the three vegetables in Val, Leu, Met, Phe, Tyr, Gly and Pro but lower than the three in Lys, Glu, His and total amino acid profiles; the following were better than A. viridis and B. alba: Thr, Ile and Asp; Cys and Ala were better in tea bush than B. alba and Ser was better in tea bush than $C$. maxima.

Total non-essential amino acid was $46.3 \mathrm{~g} / 100 \mathrm{~g}$ (53.1\%); total essential amino acid (with His ) was $42.5 \mathrm{~g} / 100 \mathrm{~g}$ protein (48.7\%) and without His was $40.9 \mathrm{~g} / 100 \mathrm{~g}$ (46.9\%). The most concentrated group of amino acids was the neutral amino acid with a total of $57.9 \mathrm{~g} / 100 \mathrm{~g}$ protein $(66.4 \%)$ and the least group was sulphur amino acid with a total value of $3.26 \mathrm{~g} / 100 \mathrm{~g}$ protein $(3.74 \%)$.

Various groups of amino acids: EAA, NEAA, SAA, AAA, etc. $(\mathrm{g} / 100 \mathrm{~g}$ protein) were also calculated. Further calculated were: total amino acid (TAA), total acidic AA (TAAA), total neutral AA (TNAA), total sulphur AA (TSAA), total aromatic AA (TArAA) and their percentage levels. Arg $(5.25 \mathrm{~g} / 100 \mathrm{~g})$ is essential for children and reasonable level was present in the leaves; the lysine content $(3.33 \mathrm{~g} / 100 \mathrm{~g}$

protein) was about one half to the content of the reference egg protein $(6.3 \mathrm{~g} / 100 \mathrm{~g})$, hence, the sample can therefore serve as half average source for Lys. The present EAA contents in tea bush are comparable to some literature values of non-conventional meat sources (g/100g): 35.1 (Zonocerus variegatus) (Adeyeye, 2005a); 42.8 (Limicolaria sp), 36.1 (Archatina archatina), 45.0 (Arhachatina marginata) (Adeyeye and Afolabi, 2004); 38.6 (heart) and 42.2 (liver) of African giant pouch rat (Cricetomys gambianus) (Adeyeye and Aremu, 2011). The content of TSAA was generally lower than the $5.8 \mathrm{~g} / 100 \mathrm{~g}$ protein recommended for infants (Anonymous, 1990). The ArAA range suggested for ideal protein $(6.8-11.8 \mathrm{~g} / 100 \mathrm{~g})$ (Anonymous, 1990) had value greater than the recommended value in the sample (13.1g/100g). The ArAA are precursors of epinephrine and thyroxin (Robinson, 1987). The percentage ratio of TEAA to the TAA in the sample $(48.7 \%)$ was better than in Moringa leaves (46.4\%) (Olaofe et al., 2013); 46.6\% in C. maxima but similar to B. alba of $48.7 \%$ (Adesina and Adeyeye, 2013) and strongly comparable to that of egg (50\%) (Anonymous, 1991) and $50.0 \%$ in $A$. viridis (Adesina and Adeyeye, 2013). The percentage ratios of TEAA to the AA in the samples were well above the $39 \%$ considered to be adequate for ideal protein food for infants, $26 \%$ for children and $11 \%$ for adults (Anonymous, 1990).

Some amino acid quality parameters were calculated for. The Leu/Ile ratio was low at 1.59; the isoelectric point of the sample was 5.32 showing that the amino acids tilted more of having acidic character which is more of animal amino acid behaviour. The $\%$ Cys/TSAA of 42.3 depicted animal protein characteristic. Predicted protein efficiency ratio (P-PER) was high (2.49) whereas the essential amino acid index (EAAI) was slightly low at 1.18 .

Most animal proteins are low in Cys and hence in Cys in TSAA. For examples, (Cys/TSAA) $\%$ were 36.3 in $M$. bellicosus (Adeyeye, 2005b); 25.6 in Z. variegatus (Adeyeye, 2005a); 35.5 in A. marginata, 38.8 in A. archatina and 21.0 in Limicolaria sp, respectively (Adeyeye and Afolabi, 2004); $23.8-30.1 \%$ in three fresh water fish consumed in Nigeria (Adeyeye, 2009) and 29.8\% in Gymnarchus niloticus (Trunk fish) (Adeyeye and Adamu, 2005). In contrast, many vegetable proteins contain substantially more Cys than Met, for examples, 62.9\% in coconut endosperm (Adeyeye, 2004; Aremu et al., 2010); its range is 58.9-72.0 in guinea corn (Adeyeye, 2008); it is $50.5 \%$ in cashew nut (Adeyeye et al., 2007); it is 40.7\% in Triticum durum (Adeyeye, 2007) and 44.4\% in Parkia biglobosa seeds (Adeyeye, 2006). In $C$. maxima, $A$. viridis and $B$. alba, the (Cys/TSAA) $\%$ values are 79.0, 40.6 and 45.0 respectively (Adesina and Adeyeye, 2013). In our present sample \%(Cys/TSAA) value was 42.3 which was much closer to the usual plant values. Thus, for animal protein, Cys is unlikely to contribute up to $50 \%$ of the TSAA (Anonymous, 1991). The \% Cys/TSAA had been set at $50 \%$ in rat, chick and pig diets (Anonymous, 1991) but not in man. Cys can spare with Met in improving the protein quality and has positive effects on mineral absorption, particularly zinc (Mendoza, 2002).

The experimentally determined PER usually ranged from 0.0 for a very poor protein to a maximum possible of just over 4.0 (Muller and Tobin, 1980). The P-PER was 2.49 in the tea bush which is better than the literature value from many plant sources: C. maxima (1.54), A. viridis (2.59) and B. alba (2.38)

(Adesina and Adeyeye, 2013); in Moringa: leaves and root (1.72 in each case) and 1.60 in the stem (Olaofe et al., 2013). Values in fish sources: 2.22, 1.92, 1.89 in three fresh water fishes (Adeyeye, 2009); liver (2.62) and heart (2.32) in African giant pouch rat (Adeyeye and Aremu, 2011). The P-PER of the whole hen's egg is 2.88 which is higher than the 
tea bush value by 0.28 or $9.72 \%$. The present result indicated that the physiological utility in the body of leaves of tea bush would be high and just about $9.72 \%$ less than that of whole hen's egg. A common feature of sorghum and maize is that the proteins of these grains contain a relatively high proportion of leucine. It was therefore suggested that an amino acid imbalance from excess Leu might be a factor in the development of pellagra (Anonymous, 1995). It has been shown that high Leu in the diet impairs the metabolism for Trp and niacin and is responsible for niacin deficiency in sorghum eaters (Ghafoorunissa and Narasinga Rao, 1973). High Leu is also a factor contributing to the pellagragenic properties of maize (Belavady and Gopalan, 1969). Further studies have shown that the biochemical and clinical manifestations of dietary excess of Leu could be counteracted not only by increasing the intake of niacin or Trp but also by supplementation with isoleucine (Belavady and Udayasekhara Rao, 1979; Krishnaswamy and Gopalan, 1971). These studies suggested that the Leu/Ile balance is more important than dietary excess of Leu alone in regulating the metabolism of Trp and niacin hence the disease process. The present Leu/Ile ratio was low at 1.59 (with Leu - Ile = 2.82 and $\% \mathrm{Leu}-\mathrm{Ile}=36.9$. Values of Leu/Ile ratio were 1.21 (leaves), 2.72 (stem) and 2.24 (root) in $M$. oleifera (Olaofe et al., 2013); 1.15 (C. maxima), 1.43 (A. viridis) and 1.33 (B. alba) (Adesina and Adeyeye, 2013). It should be noted that P-PER is a function of the value of Leu and Tyr in the sample. The present Leu value was $7.65 \mathrm{~g} / 100 \mathrm{~g}$ protein which is much less than $11.0 \mathrm{~g} / 100 \mathrm{~g}$ protein, therefore considered safe and could be beneficially exploited to prevent pellagra in endemic areas (Deosthale, 1980). The calculated

isoelectric point (pI) was 5.32. The information on $\mathrm{pI}$ is a good starting point in predicting the $\mathrm{pI}$ for proteins in order to enhance a quick precipitation of protein isolate from biological samples (Felder and Rousseau, 1986). The pI in Moringa (leaves, stem, root) ranged from 5.4-5.8 (Olaofe et al., 2013); in C. maxima, A. viridis and B. alba, the range is $4.03-5.25$. The relatively low value of $\mathrm{pI}$ could be a function of the TAAA $(18.0 \mathrm{~g} / 100 \mathrm{~g}$ protein or $20.6 \%)$ which was much higher than the TBAA $(10.2 \mathrm{~g} / 100 \mathrm{~g}$ protein or 11.7\%. The essential amino acid index (EAAI) was 1.18 which was better than in Moringa $(0.86-0.93)$ but lower than the value of 1.26 in defatted soy flour (Cavins et al., 1972) and lower than 1.55 in whole hen's egg. The EAAI method can be useful as a rapid tool to evaluate food formulation for protein quality (Nielsen, 2002).

The amino acid scores of tea bush on various standards are shown in Table III. Lys was the limiting amino acid under the various comparisons with values of: whole hen's comparison (0.537), provisional essential amino acid scoring pattern
(0.606) and pre-school essential amino acid requirement (0.574). In the whole hen's comparison, Phe, Tyr, Glu and Pro had scores greater than 1.0; in the provisional essential amino acid scoring pattern, Val, Ile, Leu, Phe + Tyr, Trp and total essential amino acid each had score greater than 1.0; in the pre-school child essential amino acid comparison, Val, Thr, Ile, Leu, Met + Cys, Phe + Tyr, Trp and total essential amino acid, each had a score greater than 1.0.

Table III shows lysine to be the limiting amino acid of the sample on the three comparisons made. However, the correction factors were not similar. In order to fulfill the daily need for the entire AA in the sample, it would require $100 / 53.7$ or 1.86 times as much leaves protein (whole hen's egg comparison), $100 / 60.6$ or 1.65 times as much leaves protein (EAA provisional scoring pattern) and 100/57.4 or 1.74 times as much leaves protein (EAA requirement for pre-school child, 2-5 y) to be eaten when they serve as the sole protein in the diet. The tea bush leaves are good sources of protein as shown in the scoring patterns where most scores were much greater than 1.0.

Table IV contains the fatty acids profile of tea bush; it also contains the fatty acids as food source, their energy contribution and the percentage energy contribution per fatty acid. The following fatty acids recorded $0.00 \%$ ( $\%$ total fatty acid of sample): C6:0, C8:0, C10:0, C12:0 and C14:0. The highest saturated fatty acid (and the highest concentrated fatty acid) was C16:0 (26.6\%) and the second highest SFA was C18:0 (4.22\%); other SFAs were each less than $0.1 \%$; total SFA being $30.9 \%$. The monoenoic fatty acids had the highest value in C18:1 (cis-9) with a value of $2.68 \%$ whereas

both $\mathrm{C} 16: 1$ (cis-9) and C18:1 (cis-6) were close at value range of $1.42-1.46 \%$ with MUFA (cis) making up a total of $5.59 \%$. The two mostly concentrated $n-6$ fatty acids were C18:2(cis-9,12)(19.9\%) and C18:3 (cis-6,9,12) (18.4\%) whereas the only $n-3$ fatty acid of significance was C18:3 (cis-9,12,15) with a value of $25.2 \%$ with overall PUFA total of $63.5 \%$. The food value of each fatty acid followed the trend of the fatty acids. The food value of C16: $0(26.6 \% \mathrm{FA})$ was $1.11 \mathrm{~g} / 100 \mathrm{~g}$ with corresponding energy value of $41.1 \mathrm{~kJ} / 100 \mathrm{~g}$ and percentage level of $26.7 \%$ whereas food from total SFA was $1.28 \mathrm{~g} / 100 \mathrm{~g}$, energy of $47.4 \mathrm{~kJ} / 100 \mathrm{~g}$, and

percentage level of $30.8 \%$. The food value was low in MUFA (cis) having just $0.233 \mathrm{~g} / 100 \mathrm{~g}$, energy value of $8.62 \mathrm{~kJ} / 100 \mathrm{~g}$ and percentage level of $5.60 \%$. C18:2 (cis-9,12) produced 0.826 $\mathrm{g} / 100 \mathrm{~g}$ as food with $30.6 \mathrm{~kJ} / 100 \mathrm{~g}$ energy occupying just $19.9 \%$; the other $n-6$ FA was C18:3 (cis-6,9,12) with food value of $0.766 \mathrm{~g} / 100 \mathrm{~g}$ and energy value of $28.3 \mathrm{~kJ} / 100 \mathrm{~g}$ with $18.4 \%$ energy. The total food value due to PUFA was $2.64 \mathrm{~g} / 100 \mathrm{~g}$, energy of $97.7 \mathrm{~kJ} / 100 \mathrm{~g}$ with percentage energy of $63.4 \%$. 
Table III. Amino acid composition of tea bush (g/100g protein dry weight sample) and their scores based on various standards

\begin{tabular}{|c|c|c|c|c|}
\hline \multirow[b]{2}{*}{ Amino acid } & \multirow[b]{2}{*}{ Value } & \multicolumn{3}{|l|}{ Scores based on: } \\
\hline & & Whole hen's egg & Provisional EAA & Pre -school EAA requirement \\
\hline $\mathrm{Val}^{\mathrm{a}}$ & 6.39 & 0.851 & 1.28 & 1.82 \\
\hline $\mathrm{Thr}^{\mathrm{a}}$ & 3.91 & 0.766 & 0.977 & 1.15 \\
\hline $\mathrm{Ile}^{\mathrm{a}}$ & 4.82 & 0.861 & 1.21 & 1.72 \\
\hline Leu $^{a}$ & 7.65 & 0.921 & 1.09 & 1.16 \\
\hline Lys ${ }^{a}$ & 3.33 & 0.537 & 0.606 & 0.574 \\
\hline Met $^{\mathrm{a}}$ & 1.88 & 0.588 & & \\
\hline Cys & 1.38 & 0.767 & 0.932 & 1.30 \\
\hline$P h e^{a}$ & 5.54 & 1.09 & & \\
\hline Tyr & 4.85 & 1.21 & 1.73 & 1.65 \\
\hline $\operatorname{Trp}{ }^{a}$ & 1.14 & 0.636 & 1.14 & 1.04 \\
\hline Gly & 6.19 & 2.06 & - & - \\
\hline Ala & 5.24 & 0.971 & - & - \\
\hline Ser & 4.33 & 0.548 & - & - \\
\hline Pro & 5.72 & 1.51 & - & - \\
\hline Asp & 6.96 & 0.651 & - & - \\
\hline Glu & 11.0 & 0.919 & - & - \\
\hline His & 1.60 & 0.665 & - & 0.840 \\
\hline Arg & 5.25 & 0.861 & - & - \\
\hline Total & 87.2 & 0.873 & 1.18 & 1.25 \\
\hline
\end{tabular}

$\mathrm{a}=$ essential amino acid.

Adequate intakes of essential fatty acids may be protecting against heart diseases and diabetes (Tumbo et al., 2002). It has been estimated that as much as $50 \%$ of the American population may consume insufficient quantities of essential fatty acids (Hu, 1999). Palmitic acid (C16:0) is a saturated fatty acid (SFA) accounting for about $27 \%$ of the fatty acids in beef. In the tea bush, the value was $26.6 \%$ of total fat being the highest concentrated fatty acid and highest concentrated SFA. Stearic acid (C18:0) is the second most abundant SFA in nature, and again it is found in the lipids of most living organisms; this observation corroborated our present report where C18:0 was $4.22 \%$. The C18:0 here is highly comparable to $2.88-3.19 \%$ in the seeds of three types of chillies consumed in Nigeria (Adeyeye et al., 2013). Total SFA in the sample was $30.9 \%$. Long-chain FAs (LCFAs) have from $14-18$ carbon and can either be SFA, MUFA or 
Table IV. Fatty acids composition of tea bush (\% total fatty acids); as food source (g/100g); energy contributi on $(\mathrm{kJ} / \mathbf{1 0 0 g})$ and its percentage

\begin{tabular}{|c|c|c|c|}
\hline Fatty acid & Acid value & Food value & Energy value \\
\hline $\mathrm{C} 16: 0$ & 26.6 & 1.11 & $41.1(26.7 \%)$ \\
\hline C18:0 & 4.22 & 0.176 & $6.51(4.23 \%)$ \\
\hline C20:0 & 0.011 & $4.674 \mathrm{e}-4$ & $1.73 \mathrm{e}-2(0.011 \%)$ \\
\hline $\mathrm{C} 22: 0$ & 0.010 & $4.313 \mathrm{e}-4$ & $1.20 \mathrm{e}-2(0.01 \%)$ \\
\hline $\mathrm{C} 24: 0$ & 0.001 & $5.325 \mathrm{e}-5$ & $1.97 \mathrm{e}-3(0.001 \%)$ \\
\hline SFA & 30.9 & 1.28 & $47.4(30.8 \%)$ \\
\hline $\mathrm{C} 14: 1($ cis -9$)$ & 0.00 & - & - \\
\hline $\mathrm{C} 16: 1(\mathrm{cis}-9)$ & 1.46 & 0.061 & $2.26(1.47 \%)$ \\
\hline $\mathrm{C} 18: 1($ cis -6$)$ & 1.42 & $5.890 \mathrm{e}-2$ & $2.18(1.42 \%)$ \\
\hline C18:1( cis -9) & 2.68 & $1.112 \mathrm{e}-1$ & $4.11(2.67 \%)$ \\
\hline $\mathrm{C} 20: 1($ cis -11$)$ & 0.019 & $7.850 \mathrm{e}-4$ & $2.90 \mathrm{e}-2(0.019 \%)$ \\
\hline $\mathrm{C} 22: 1($ cis -13$)$ & 0.015 & $6.289 \mathrm{e}-4$ & $2.33 \mathrm{e}-2(0.015 \%)$ \\
\hline $\mathrm{C} 24: 1($ cis -15$)$ & 0.001 & $5.325 \mathrm{e}-5$ & $1.97 \mathrm{e}-3(0.001 \%)$ \\
\hline MUFA ( cis ) & 5.59 & 0.233 & $8.62(5.60 \%)$ \\
\hline C18:1( trans -6$)$ & 0.004 & $1.681 \mathrm{e}-4$ & $6.22 \mathrm{e}-3(0.004 \%)$ \\
\hline C18:1( trans -9$)$ & 0.0004 & $1.523 \mathrm{e}-5$ & $5.64 \mathrm{e}-4(0.0004 \%)$ \\
\hline C18:1( trans -11$)$ & 0.00 & - & - \\
\hline MUFA ( trans ) & 0.0044 & $1.830 \mathrm{e}-4$ & $6.77 \mathrm{e}-3(0.0044 \%)$ \\
\hline $\mathrm{C} 18: 2($ cis $-9,12)$ & 19.9 & 0.826 & $30.6(19.9 \%)$ \\
\hline $\mathrm{C} 18: 2($ trans -9 , cis -11$)$ & 0.005 & $1.971 \mathrm{e}-4$ & $7.29 \mathrm{e}-3(0.005 \%)$ \\
\hline $\mathrm{C} 18: 3($ cis $-6,9,12)$ & 18.4 & 0.766 & $28.3(18.4 \%)$ \\
\hline $\mathrm{C} 18: 3($ cis $-9,12,15)$ & 25.2 & 1.05 & $38.9(25.3 \%)$ \\
\hline $\mathrm{C} 20: 2(\mathrm{cis} \quad-11,14)$ & 0.002 & $6.619 \mathrm{e}-5$ & $2.45 \mathrm{e}-3(0.002 \%)$ \\
\hline C20:3( cis $-8,11,14)$ & 0.013 & $5.455 \mathrm{e}-4$ & $2.02 \mathrm{e}-2(0.013 \%)$ \\
\hline $\mathrm{C} 20: 3($ cis $-11,14,17)$ & 0.007 & $2.860 \mathrm{e}-4$ & - \\
\hline $\mathrm{C} 20: 4($ cis $-5,8,11,14)$ & 0.00 & - & - \\
\hline $\mathrm{C} 22: 2($ cis $-13,16)$ & 0.007 & $3.006 \mathrm{e}-4$ & $1.06 \mathrm{e}-2(0.007 \%)$ \\
\hline $\mathrm{C} 20: 5$ (cis $-5,8,11,14,17$ ) & 0.008 & $3.153 \mathrm{e}-4$ & $1.17 \mathrm{e}-2(0.008 \%)$ \\
\hline C22:6( cis $-4,7,10,13,16,19)$ & 0.005 & $2.262 \mathrm{e}-4$ & $9.69 \mathrm{r}-3(0.006 \%)$ \\
\hline PUFA total & 63.5 & 2.64 & $97.7(63.4 \%)$ \\
\hline
\end{tabular}

PUFA. Stearic acid is an 18-carbon SFA, oleic acid and petroselinic acid are both 18-carbon MUFA. Another MUFA is the 16-carbon palmitoleic acid which has strong antimicrobial properties (it was $1.46 \%$ in the present sample).
The two EFAs are also long-chain, each 18 carbons in length. Very-long-chain fatty acids (VLCFAs) have $20-24$ carbon atoms. Some people can make these FAs from EFAs, but others, particularly those whose ancestors ate a lot of fish, 
lack enzymes to produce them. These "obligate carnivores" must obtain them from animal foods such as organ meats, egg yolks, butter and fish oils. All the VLCFAs in the present study were of very low and insignificant levels just like we have in pepper seeds (Adeyeye et al., 2013).

Some benefits have been attributed to SFA. They include: SFA constitute at least $50 \%$ of cell membranes, they are what give our cells necessary stiffness and integrity; they play a vital role in the health of our bones, for $\mathrm{Ca}$ to be effectively incorporated into the skeletal structure, at least $50 \%$ of the dietary fats should be saturated (Watkins and Seifert, 1996); they lower Lp(a), a substance in the blood that indicates proneness to heart disease (Dahlen et al., 1998); they protect the liver from alcohol and other toxins, such as Tylenol

(Nanji et al.,1995); they enhance the immune system (Kabara, 1978); they are needed for the proper utilization of EFAs, elongated omega-3 FAs are better retained in the tissue when the diet is rich in SFA (Adeyeye and Adesina, 2013); C16:0 and C18:0 are the preferred foods for the heart, which is why the fat around the heart muscle is highly saturated (Daley et al., 2010), the heart draws on this reserve of fat in times of stress; short and medium chain SFA (SCFAs, 4-6 carbon atoms; MCFAs, 8-12 carbon atoms) have important antimicrobial properties, they protect us against harmful microorganisms in the digestive tract. C6:0-C14:0 had $0.00 \%$ each in the sample. The much-maligned SFA may not be the cause of our modern diseases after all.

The oleic acid (Table IV) formed a value of $2.68 \%$ among the MUFA (cis) in the sample. There is epidemiological evidence that dietary MUFA have a beneficial effect on the risk of CHD. Moreover, evidence from controlled clinical studies have shown that MUFAs favourably affect a number of risk factors for CHD, including plasma lipids and lipoproteins, factors related to thrombosis, in vitro LDL oxidative susceptibility (compared with PUFA), and insulin sensitivity. Compared with SFA, MUFAs lower total and LDL cholesterol levels, and relative to carbohydrate, they increase HDL cholesterol levels and decrease plasma triglyceride levels (Kris-Etherton, 1999). A diet high in MUFA (versus a high-carbohydrate diet) improves glycemic control in individuals with NIDDM who maintain body weight. Individuals with elevated triglycerides or insulin also

may benefit from a high - MUFA diet (Kris-Etherton, 1999). The total MUFA (cis) was low at 5.59\% whereas the MUFA (trans) values ranged from $0.00 \%-0.004 \%$ thereby deserving no discussion. Oleic acid was low also in Moringa leaves $(4.28 \%)$, stem $(0.80 \%)$ but very high in root $(38.2 \%)$ (Olaofe et al., 2013). Oleic acid is the biosynthetic precursor of a family of fatty acids with the $(n-9)$ terminal structure and with chain-lengths of 20-24 or more. Petroselinic acid (6 cis $-18: 1$ ) occurs up to a level of $50 \%$ or more in seed oils of the Umbelliferae family, including carrot, parsely and coriander. In the present report, petroselinic acid occupied a level of $1.42 \%$ being third highest MUFA (cis). Petroselinic acid is synthesized by enzyme that removes hydrogen from position 4 of palmitate, before the resulting $4-16$ : 1 is elongated by two carbon atoms (Adeyeye and Aye, 2013).

16:0 desaturation 4-16:1 elongation 6:18:1 (petroselinic acid)

Within the concept of a 'balance' among classes of SFA, MUFA and PUFA is the issue of which specific SFA or PUFA are best. Many studies have suggested that SFA raise TC, LDL and HDL, and that PUFA lower them. But certain SFA (as consumed in our daily diet ) are better than others in terms of their impact on the LDL/HDL ratio. Fats rich in 12:0 + 14:0 (e.g., milk fat, coconut oil and palm kernel oil) raise LDL the most. Stearic acid (C18:0) is not very prevalent in saturated fats (as seen in this sample), but it is neutral in its effect on blood cholesterol when consumed in natural fats. The most common SFA is palmitic acid (16:0), so named because it represents the major SFA in palm oil. The 16:0 SFA is present to some degree in essentially all fats and is by far the most prevalent SFA in our diet. Considering the influence on the lipoprotein profile, 16:0 is intermediate, that is, it can be neutral when placed in a triglyceride molecule with MUFA, PUFA or 18:0, or cholesterol - raising when attached along with 12:0 + 14:0. In high amounts, 16:0 can even raise TC and LDL when substituted for 18:0, MUFA or PUFA in people who already have elevated TC or eat large amounts of cholesterol. Accordingly, the general advice has been to remove as much SFA from the diet as possible. But this is not practical because the manufacture of many food products requires SFA (or some facsimile thereof), such as trans fatty acids (TFA), and extreme removal of dietary SFA is not prudent because their deletion from the diet surprisingly exerts an adverse effect on the LDL/HDL ratio (Hayes, 2002). It is gratifying to note that both $\mathrm{C} 12: 0$ and $\mathrm{C} 14: 0$ each had a value of $0.00 \%$ and $\mathrm{C} 16: 0$ was low at $26.6 \%$.

In the consideration of balance among the PUFA, the issue of whether to include linoleic acid (18:2n-6), linolenic acid

(18:3n-3) or longer $n-3$ fatty acids like eicosapantaenoic acid and docosapentaenoic acid must be considered. Both $n-6$ and $n-3$ families are essential fatty acids and both are important to health, especially cardiovascular health. The linoleic acid (LA) level has the greatest impact on regulating the LDL/HDL ratio, whereas linolenic acid (ALA) and its longer 
derivatives have a major influence over clotting mechanism, as well as stabilizing the heart against abnormal beating (arrhymia) that can lead to sudden death. Diets enriched in $18: 3 n-3$ or 22:6 n-3 have been shown to exert significant anti-CHD effects in humans both in clinical and epidemiological studies (Hayes, 2002). Both LA (19.9\%) and ALA (25.2\%) were high in the sample. Another

important $n-6$ fatty acid in the sample was C18:3 cis $6,9,12$ (gamma-linolenic acid), a desaturation product of linoleic

acid; present in the seeds of borage, blackcurrant and evening primrose (Beare-Rogers et al., 2001). The body makes GLA out of omega- 6 linoleic acid and uses it in the production of substances called prostaglandins, localized tissue hormones that regulate many processes at the cellular level.

Column 3 in Table IV contained fatty acid profile $(\mathrm{g} / 100 \mathrm{~g})$ of the sample as food source. It showed the level of fatty acids when the sample is consumed as food. This type of information is required to be able to calculate the energy contribution by each type of fatty acid. The concentration of the fatty acids as food went as (g/100g) PUFA (2.64) > SFA (1.28) > MUFA (cis) (0.233).

Column 4 in Table IV contained the energy contribution of the fatty acids in the sample. Some notable energy contributions were $(\mathrm{kJ} / 100 \mathrm{~g})$ : $\mathrm{C} 16: 0$ (41.1 or $26.7 \%)$; $\mathrm{C} 18: 0$ ( 0.176 or $6.51 \%)$; SFA (47.4 or $20.8 \%$ ); C16:1 cis -9 (2.26 or 1.47\%): C18:1 cis -6 (2.18 or $1.42 \%)$; C18:1 cis -9 (4.11 or 2.67\%); MUFA (cis) (8.62 or 5.60\%); C18:2 cis-9, 12 (30.6 or $19.9 \%$ ); $\mathrm{C} 18: 3$ cis- $6,9,12$ (28.3 or $18.4 \%$ ), C18:3 cis- $-9,12$, 15 (38.9 or $25.3 \%$ ) and PUFA (97.7 or $63.4 \%$ ). On the other hand, the percentage contribution of energy to total energy in SFA due to $\mathrm{C} 16: 0$ was $87.7 \%$ and $\mathrm{C} 18: 0$ was $13.7 \%$; in MUFA (cis), energy contribution due to C18:1 cis -6 was 25.3\%; C18:1 cis-9 was $47.7 \%$ and $\mathrm{C} 16: 1$ cis-9 was $26.2 \%$; in PUFA, energy contribution due to C18:2 cis $-9,12$ was $31.3 \%$; C18:3 cis-6, 9,12 was $29.0 \%$ and $\mathrm{C} 18: 3$ cis-9,12,15 was $39.8 \%$. In the sample total energy intake from it as contributed from SFA was greater than $10 \% \mathrm{E}$ but the recommended range ADMR (acceptable macronutrient distribution range) for PUFA is $6.11 \% \mathrm{E}$ (WHO, 2010) was less than our values; our results therefore could lead to the replacement of SFA with PUFA ( $n-3$ and $n-6)$ in the diet.

Some fatty acid quality parameters were calculated. The ratio of linoleic acid (LA) and alpha linolenic acid (ALA), LA/ALA had a value of 0.787 whereas $n-6 / n-3$ ratio was 1.52. MUFA+PUFA gave a value of $69.1 \%$ showing the fatty acids to be mostly unsaturated; PUFA/SFA was 2.06 showing the fatty acids to be good nutritionally in not promoting coronary heart diseases. The essential PUFA status index was high at 11.4 because the sample was much higher in PUFA than in MUFA; the EPA/DHA was low because both EPA $(0.008 \%)$ and DHA $(0.005 \%)$ were low in the sample.

The original American Heart Association (AHA) Step 1 fat recommendation was perceptive because it recognized the significance of the fatty acid balance at approximately $1: 1: 1$

for SFA:MUFA:PUFA. Careful review of numerous reports in the literature has revealed the importance of this balance for generating the best LDL/HDL ratio. Furthermore, it would appear that the balance is critical at any level if fat intake of one wishes to avoid adversely affecting the lipoprotein profile (Hayes, 2002). The best dietary fat would contain an ideal balance $(7: 1)$ of $n-6$ linoleic to $n-3$ linolenic acids. This balance is not available in partially hydrogenated margarines, in which most of the $n-3$ linolenic acid has been destroyed by processing, and is also unlike most vegetable oils that contain only a small amount of this important fatty acid (Hayes, 2002). Our LA/ALA result showed a value of 0.787 which highly deviated from $7: 1$ as recommended above; the reason had been due to the unusual low level of LA (19.9\%) compared to ALA (25.2\%) probably due to desaturation of LA to form GLA (18.4\%) about equal the value of LA. The ratio of PUFA/SFA ( $\mathrm{P} / \mathrm{S}$ ratio) is important in determining the detrimental effects of dietary fats. The higher the $\mathrm{P} / \mathrm{S}$ ratio the more nutritionally useful is the dietary oil. This is because the severity of atherosclerosis is closely associated with the proportion of the total energy supplied by SFA and PUFA fats (Honatra, 1974). The present result had $\mathrm{P} / \mathrm{S}$ ratio of 2.06 which is positive towards PUFA more than SFA. The relative proportion of MUFA/SFA is an important aspect of phospholipid compositions and changes to this ratio have been claimed to have effects on such disease states as cardiovascular disease, obesity, diabetes, neuropathological conditions and cancer. The MUFA/SFA level in the sample was low as 0.181 due to low level of MUFA versus high level of SFA. MUFA/SFA has been shown to have cytoprotective actions in pancreatic $\beta$-cells. cis - Monoenoic acids have desirable physical properties for membrane lipids in that they are liquid at body temperature, yet are resistant to oxidation. They are now recognized by nutritionists as being beneficial in human diet (Olaofe et al., 2013). A suitable indicator of essential PUFA status is the essential PUFA status index (EPSI), which is the ratio between all essential PUFA (the sum of all $n-3$ and $n-6$ FAs) and all non essential unsaturated

FAs (the sum of all $n-7$ and $n$-9 FAs). The higher the EPSI, the better the essential PUFA status. The EPSI value in tea bush was 11.4. The EPA/DHA value was 1.39 and no Mead acid (20:3 cis-9) was produced showing that the PUFA would be functional (Benatti et al., 2004). From our calculation, the 
SFA:MUFA:PUFA in the sample was 1:5.53:0.49. The original AHA step I fat recommendation ( $\leq 30 \%$ fat, $8 \%$ $10 \%$ SFA and $<300 \mathrm{mg}$ of cholesterol per day) (Kris-Etherton, 1999) was perceptive because it recognised the significance of the fatty acid balance at approximately 1:1:1 for SFA:MUFA:PUFA. The importance of this balance for generating the best LDL/HDL ratio had been reviewed (Hayes, 2002).

The phospholipid levels were depicted in Table V. brain, nerves, neutral tissue and in spinal cord (Adeyeye, 2011). Lysophosphatidylcholine (LPC) occupied the fourth position in abundance with a value of $3.71 \mathrm{mg} / 100 \mathrm{~g}(8.41 \%)$. Partial hydrolysis of lecithin with removal of only one fatty acid yields a lysophosphatidylcholine. An example of alterations in enzyme activity related to association of a membrane-bound protein with lipid is that of phenylalanine hydroxylase, which catalyses the conversion of phenylalanine to tyrosine. The activity of those enzymes, attached to the endosplasmic reticulum, is enhanced fifty fold

Table V. Phospholipids level of the tea bush sample (mg/100g)

\begin{tabular}{|c|c|c|}
\hline Phospholipids & Value & Percentage value \\
\hline Phosphatidylethanolamine (Cephalin, PE) & 7.53 & 17.1 \\
\hline Phosphatidylcholine (Lecithin, PC) & 15.9 & 35.9 \\
\hline Phosphatidylserine (Ptd-L-Ser, PS) & 2.10 & 4.76 \\
\hline Lysophosphatidylcholine & 3.71 & 8.41 \\
\hline Phosphatidylinositol (PI) & 14.9 & 33.8 \\
\hline Total & 44.1 & - \\
\hline
\end{tabular}

Phosphatidylcholine (lecithin, PC) is usually the most abundant phospholipid in animals and plants, often amounting to almost $50 \%$ of the total, and as such it is the key building block of membrane bilayers. This observation is true for lecithin in the sample $(15.9 \mathrm{mg} / 100 \mathrm{~g}$ or $35.9 \%)$. Lecithin is also the principal phospholipid circulating in plasma, where it is an integral component of the lipoproteins, especially the HDL. Large doses of lecithin may cause gastrointestinal upsets, sweating, salivation and loss of appetite (Whitney et al., 1994). Phosphatidylinositol (PtdIns, $\mathrm{PI}$ ) is a negatively charged phospholipid and a minor component in the cytosolic site of eukaryotic cell membranes. The inositol can be phosphorylated to form phospatidylinositol phosphate (PIP), phosphatidylinositol bisphosphate $\left(\mathrm{PIP}_{2}\right)$ and phosphatidylinositol trisphosphate $\left(\mathrm{PIP}_{3}\right)$. PIP, PIP and $\mathrm{PIP}_{3}$ are collectively called phosphoinositides. Phosphoinositides play important roles in lipid signaling, cell signaling and membrane trafficking (Adeyeye, 2011). PI was in the second position in abundance $(14.9 \mathrm{mg} / 100 \mathrm{~g}, \quad 33.8 \%)$ in the sample. Phosphatidylethanolamine (cephalin, PE) was the third largest in abundance $(7.53 \mathrm{mg} / 100 \mathrm{~g}, 17.1 \%)$. PE is found in all living cells, although in human physiology it is found particularly in nervous tissue such as the white matter of in the presence of lysophosphatidylcholine, with which it probably complexes in the hepatic cell. Phosphatidylserine (PS) was the least concentrated phospholipid having a value of $2.10 \mathrm{mg} / 100 \mathrm{~g}(4.76 \%)$. Phosphatidylserine (Ptd-L-Ser or PS) supplementation promotes a desirable hormonal balance for athletes and might attenuate the physiological deterioration that accompanies overtraining and/or overstretching (Starks et al., 2008). In recent studies, PS has been shown to enhance mood in a cohort of young people during mental stress and to improve accuracy during tee-off

by increasing the stress resistance of golfers. The US Food and Drug Administration (USFDA) had stated that the consumption of PS may reduce the risk of dementia in the elderly and may also reduce the risk of cognitive dysfunction in the elderly.

In Table VI, we have the phytosterols data. Good enough, cholesterol had $0.00 \mathrm{mg} / 100 \mathrm{~g}$ although the sterols were generally low in concentration with total value of $42.8 \mathrm{mg} / 100 \mathrm{~g}$. The plant sterols still showed better prominence than the usual animal sterols as shown: plant sterols $(\mathrm{mg} / 100 \mathrm{~g})$, sitosterol $(26.3$ or $61.5 \%)>$ campesterol $(8.14$ or $19.0 \%)>$ stig-masterol $(4.42$ or $10.3 \%)$ and 
Table VI. Phytosterols level of the tea bush sample (mg/100g)

\begin{tabular}{|c|c|c|c|}
\hline Sterols & Value & & Percentage value \\
\hline Cholesterol & 0.00 & & 0.00 \\
\hline Cholestanol & $1.04004 \mathrm{e}$ & -5 & $2.4322 \mathrm{e}-5$ \\
\hline Ergosterol & $1.83716 \mathrm{e}$ & -3 & 4.30 \\
\hline Campesterol & 8.14 & & 19.0 \\
\hline Stig -masterol & 4.42 & & 10.3 \\
\hline 5 - Avenasterol & 3.89 & & 9.10 \\
\hline Sitosterol & 26.3 & & 61.5 \\
\hline Total & 42.8 & & - \\
\hline
\end{tabular}

5-avenasterol (3.89 or $9.10 \%)$ whereas in usual animal sterols $(\mathrm{mg} / 100 \mathrm{~g})$, ergosterol $(1.83 \mathrm{e}-3$ or $4.30 \mathrm{e}-3 \%)>$ cholestanol (1.04 e-5 or 2.43 e-5\%).

The cholesterol - lowering effect of dietary plant sterols (phytosterols) has been studied since the 1950s and is well known (Lees et al., 1977). Earlier studies showed that large amounts of sitosterol $(\geq 10 \mathrm{~g} / \mathrm{d})$ lowered serum cholesterol levels by $10-20 \%$. The high dosage and the chalky taste of sitosterol limited its use, especially with the advent of the more powerful, well-tolerated, lipid-lowering 3-hydroxy-3-methylglutaryl enzyme A reductase inhibitors. Grundy (Grundy, 1994) subsequently demonstrated that $3 \mathrm{~g} / \mathrm{d}$ of sitosterol was sufficient to lower serum cholesterol levels. They suggested that plant sterol could be considered a form of dietary treatment rather than a drug to lower cholesterols because plant sterols are naturally present in plant based foods.

\section{Conclusion}

The tea bush sample was low in total fatty acid; hence its consumption may not overload the body with high fat food. Deleterious C12:0 and C14:0 recorded 0.00\% (each) thereby removing the fear of their promoting heart diseases. The proximate composition was high in protein, fibre and ash. The major and trace minerals were high and most minerals quality parameters were within standards. The amino acids were of high quality with their scores showing them to be better concentrated than many compared standards although Lys was limiting in all the comparisons. Both phospholipids and sterols were low but cholesterol had a value of 0.00 $\mathrm{mg} / 100 \mathrm{~g}$ whereas most important plant sterol (sitosterol) was the most concentrated phytosterol; this sterol had been found to be very good in preventing the absorption of cholesterol into the blood stream.

\section{References}

Adesina A J and Adeyeye E I (2013), Amino acid profile of three non conventional leafy vegetables: Cucurbita maxima, Amaranthus viridis and Basella alba, IJAPS. 3(1): $1-10$.

Adeyeye E I (1996), Waste yield, proximate and mineral composition of three different types of land snails found in Nigeria, Int J Food Sci Nutr. 47: 111 - 116.

Adeyeye E I (2004), The composition of liquid and solid endosperm of ripe Coconut, Orient J Chem. 20(3): $471-476$.

Adeyeye E I (2005a), Amino acid composition of variegated grasshopper, Zonocerus variegatus, Trop Sci. 45(4): $141-143$.

Adeyeye E I (2005b), The composition of the winged termites, Macrotermes bellicossus, J Chem Soc Nig. 30(2): $145-149$.

Adeyeye E I (2006), Amino acid composition of fermented African locust bean (Parkia biglobosa) seeds, J Appl Environ Sci. 2(2): 154 - 158.

Adeyeye E I (2007), Amino acids and sugar composition of Triticum durum whole mean flour. J. Appl. Environ. Sci. 3(2): $128-132$.

Adeyeye E I (2008), The intercorrelation of the amino acid quality betweenraw, steeped and germinated guinea corn (Sorghum bicolor) grains, Bull Chem Soc Ethiop. 22(1): $1-7$.

Adeyeye E I (2009), Amino acid composition of three species of Nigerian fish: Clarias anguillaris, Oreochromis niloticus and Cynoglossus senegalensis, Food Chem. 3(2): $265-272$.

Adeyeye E I (2011), Levels of fatty acids, phospholipids and sterols in the skin and muscle of tilapia (Oreochromis niloticus) fish, La R I S G LXXXVIII (Gennaio/Marzo): 46 - 55.

Adeyeye E I (2013), Proximate, mineral and antinutrient composition of dika nut (Irvingia gabonensis) kernel. Elixir Food Science. 58 (2013): 14902 - 14906. 
Adeyeye E I and Adamu A S (2005), Chemical composition and food properties of Gymnarchus niloticus (Trunk fish), Biosci Biotechl Res Asia. 3(2): 265 - 272.

Adeyeye E I and Adesina A J (2013), Enhancement of lipid quality of raw guinea corn (Sorghum bicolor) grains through germination and steeping, Open J Analytical Res. 1 (1): $5-17$.

Adeyeye E I and Afolabi E O (2004), Amino acid composition of three different types of land snails consumed in Nigeria, Food Chem, 85: 535 - 539.

Adeyeye E I and Aremu M O (2011), Amino acid composition of two fancy meats (liver and heart) of African giant pouch rat (Cricetomys gambianus), Orient J Chem. 27(4): 1409 - 1419.

Adeyeye E I and Aye P A (2013), Lipid composition of three organs of Hippotragus equinus (Roan Antelope), Elixir Food Science. 58 (2013): 14891 - 14901.

Adeyeye E I, Asaolu S S and Aluko A O (2007), Amino acid composition of two masticatory nuts (Cola acuminata and Garcinia kola) and a snack nut (Anacardium occidentale), Int J Food Sci Nutr. 58(4): 241- 249.

Adeyeye E I, Jimoh A O and Adesina A J (2013), Lipid composition of the seeds of three types of chillies consumed in Nigeria, Open J Org Chem. 1(3): 69 - 79.

Akinadewo O (2001), Medicinal Plants and their Therapeutic Uses in the South West Zone of Nigeria (Ekiti, Lagos, Ogun, Ondo, Osun, Oyo States). Nigeria Natural Medicine Development Agency (Fed. Min. Sci. Technol., Abuja, Nigeria) 2001, pp. 59 - 60 .

Aliyu A B, Musa A M, Sallau M S and Oyewale A O (2009), Proximate composition, mineral elements and anti-nutritional factors of Anisopus mannii N.E.Br. (Asclepiadaceae), Trends Appl Sci Res. 4(1):68-72.

Alsmeyer R H, Cunningham A E and Happich M L (1974), Equations to predict PER from amino acid analysis, Food Technol. 28: $34-38$.

Anderson B A (1976), Comprehensive evaluation of fatty acids in foods. VII. Pork products, J American Diet Ass. 69: 44-49.

Aremu M O, Olaofe O, Basu S K, Abdulazeez G and Acharya S N (2010), Processed cranberry bean (Phaseolus coccineus) seed flours for African diet, Can J Plant Sci. 90: $718-728$.

Anonymous, AOAC (Association of Official Analytical Chemists) (2006), Official Methods of Analysis. 18 ${ }^{\text {th }}$ Ed. (Association of Official Analytical Chemistry, Washington DC) 2006.
Anonymous, FAO (1995), Sorghum and Millets in Human Nutrition. FAO Food and Nutrition Series No. 27. (FAO/UNU, Rome) 1995, p. 121.

Anonymous, FAO/WHO (1973), Energy and Protein Requirements. Technical Report Series No. 522. (WHO, Geneva) 1975, p.118.

Anonymous, FAO/WHO (1990), Protein Quality Evaluation. Report of Joint FAO/WHO Consultation Held in Bethesda, USA, 4 - 8 Decmber, 1989. (FAO Rome) 1990, pp. 3-7.

Anonymous, FAO/WHO (1991), Protein Quality Evaluation. Report of Joint FAO/WHO Expert Consultation, FAO Food and Nutrition Paper 51. (FAO, Rome) 1991, pp. 3-7.

Anonymous, FAO/WHO/UNU (1985), Energy and Protein Requirement. WHO Technical Report Series No. 724. (WHO, Geneva) 1985, pp. 53-112.

Babeau W E (1989), Nutritional evaluation of experimental weaning foods prepared from green leaves, peanut oil and legume flour, Plant Foods for Hum Nutr. 39: 381 - 392.

Beare-Rogers J, Dieffenbacher A and Holm J V (2001), Lexicon of Lipid Nutrition (IUPAC Technical Report), Pure Appl Chem. 73(4): 685 - 744.

Belavady B and Gopalan C (1969). The role of leucine in the pathogenesis of canine black tongue and pellagra, Lancet, 2: 956 - 957.

Belavady B and Udayasekhara Rao P (1979), Leucine and isoleucine content of jowar and its pellagragenicity, Ind J Expt Bio. 17: 659 - 661.

Benatti P, Peluso G, Nicolai R and Calvani M (2004), Polyunsaturated fatty acids: biochemical, nutritional and epigenetic properties, J Am Coll Nutr. 33 (4): 281 - 302.

Byers M (1961), Extraction of proteins from the leaves of some plants growing in Ghana, J Sci Food Agric. 12: 20 - 30.

Cavins J C, Kwolek D F, Inglett G E and Cowen J C (1972) Amino acid analysis of soybean meal: interlaboratory study, J Ass Off Analy Chem. 55: 686 - 694.

Champe PC andHarvey R A (1994), Lippincott's Illustrated Reviews: Biochemistry. 2nd Ed. (Lippincott Raven Publishers, New Jersey, USA) 1994, pp. 303 - 340.

Crosby NT (1977), Determination of metals in foods: a review. The Analyst. 102: 225 - 267.

Daley C A, Abbott A, Doyle PS, Nader G A and Larson S (2010), Grass fed versus grain fed beef fatty acid profiles, anti oxidant content and taste, Nutr J. 9: 10-21. 
Dahlen G H, Srinivasan S R, Stenlund H, Wattigney W A, Wall S and Berenson G S (1998). The importance of serum lipoprotein (a) as an independenat risk factor for premature coronary artery disease in middle-aged black and white women from the United States. $J$ Intern Med. 244: 417 - 424.

Davies J and Dickerson J (1991), Nutrient content of food portions. (Royal Society of Chemistry, Cambridge) 1991, pp. 1-53.

Deosthale Y G (1980), Nutrition dimension of high yielding and hybrid crop varieties: locational and varietal differences in nutritional value. In: FAO: Sorghum and millet in human nutrition. FAO Food and Nutrition Series, No. 27, (FAO, Rome) 1995, p. 82.

Eggum B O (1970), Protein quality of cassava leaves. $\mathrm{Br} J$ Nutr. 24:761-768.

Felder R M and Rausseau R W (1986), Elementary Principles of Chemical Processes, 2nd Ed. (John Wiley and Sons, London) 1986, pp. 1-353.

Finar I L (1975), Organic Chemistry, Vol. 2, 5th Ed. (ELBS and Longman Group, London) 1975, p. 524.

Gbile Z O (1984), Vernacular Names of Nigerian Plants (Yoruba). Forestry Research Institute of Nigeria, Ibadan. [The Caxton Press (West Africa) Ltd., Ibadan] 1984, pp. 21-22.

Ghafoorunissa S and Narasinga Rao B S (1973), Effect of leucine on enzymes of the tryptophan - niacin metabolic pathway in rat liver and kidney, Biochemical J. 134: 425-430.

Greenfield H and Southgate DAT (2003), Food Composition Data: Production, Management and Use. (FAO, Rome) 2003, p. 224.

Grundy S M (1994), Influence of stearic acid on cholesterol metabolism relative to other long-chain fatty acids, $\mathrm{Am}$ J Clin Nutr. 60 (Supp): 986S-990S.

Hayes K C (2002), Dietary fat and heart health: in search of the ideal fat, Asia Pacific J Clin Nutr. 11(Suppl): S394- S400.

Honatra G (1974), Dietary fats and arterial thrombosis, Haemostasis. 2: 21-52.

Hu F B, Stampfer M J, Manson J E, Rimm E B, Wolk A, Colditz G A, Hennekens C H and Willett W C (1999), Dietary intake of alpha-linolenic acid and risk of fatal ischemic heart disease among women, Am J Clin Nutr. 69: 890-897.
Hutchinson J, Dalziel J N and Hepper F N (1963), Flora of West Troipical Africa. 2nd Ed, Vol II. (Crown Agents, London) 1963, pp. 450-452.

Kabara J J (1978), The Pharmacological Effect of Lipids. (The American Oil Chemists' Society, Champaign IL) 1978.

Kilgour OFG (1987), Mastering Nutrition. (Macmillan Education Ltd., London) 1987, pp. 94-99.

Kochhar S L (1986), Tropical Crop. (Macmillan Publishers, London) 1986. pp. 310-316.

Kris-Etherton PM (1999), Monounsaturated fatty acids and risk of cardiovascular disease, Circulation, 100: 1258.

Krishnaswamy K C and Gopalan C (1971). Effect of isoleucine on skin and electroencephalogram in pellagara, Lancet. 2: 1167-1169.

Lees A M, Mok H Y, Lees R S, McCluskey M A and Groundy S M (1977), Plant sterols as cholesterol-lowering agents: clinical trials in patients with hypercholesterolemia and studies of sterol balance, Atherosclerosis. 28: 325-338.

Marten G C and Andersen R N (1975) Forage, nutritive value and palatability of 12 common annual weeds, Crop science. 111:829-837.

Mendoza C (2002), Effect of genetically modified low phytic acid plants on mineral absorption, Int J Food Sci Nutr. 37:759-767.

Mudambi S R and Rajagopal M W (1983), Fundaamentals of Food and Nutrition. 2nd Ed. (Wiley Eastern Ltd., New Delhi) 1983, pp. 224.

Muller H G andTobin G (1980), Nutrition and Food Processing. (Croom Helm, London) 1980, p. 302.

Nanji A A, Zhao S and Sadrazade M M (1995), Experimental liver cirrhosis induced by alcohol and iron, Gastroenterology. 109: 547-554.

NRC (National Research Council) (1989), Food and Nutrition Board, Recommended Dietary Allowances. 10th Ed. (National Academy of Sciences-National Research Council, National Academy Press, Washington D C) 1989, pp. 82-92.

Nielsen S S (2002), Introduction to the Chemical Analysis of Foods. (CBS Publishers and Distributors, New Delhi, India) 2002. 
Nieman D C, Butterwworth D E and Nieman C N (1992), Nutrition. (Wm C Brown Publishers, Dubuque, USA) 1992, pp. 19-426.

Oke O L (1973), Leaf protein research in Nigeria: a review. Trop Sci. 15:139 - 155.

Olaofe O and Akintayo E T (2000), Prediction of isoelectric points of legume oilseed proteins from their amino acid composition. The J Technosci. 4: 49-53.

Olaofe O, Adeyeye E I and Ojugbo S (2013), Comparative study of proximate, amino acids and fatty acids of Moringa oleifera tree, Elixir Appl. Chem. 54 (2013): 12543- 12554.

Omoyeni O A and Adeyeye E I (2009), Chemical composition, calcium, inc and phytate interrelationships in Aerva lanata (Linn) Juss. ex Schult leaves, Orient J Chem. 25(3): 485-488.

Paul A A and Southgate DAT (1978), McCance and Widdowson's The Composition of Foods, 4th Ed. (Her Majesty's Stationery Office, London) 1978 pp. 279-287.

Pearson D (1976), Chemical Analysis of Foods. 7th Ed. (Churchill Livingstone, London ) 1976. pp. 7-11.

Raheja R K, Kaur C, Singh A and Bhatia IS (1973), New colorimetric method for the quantitative estimation of phospholipids without acid digestion, J Lip Res. 14:695 - 697 .

Robinson D E (1987), Food Biochemistry and Nutrition Value. (Longman Scientific and Technical, London) 1987.

Selvendran R R, Ring S G and Duport M S (1979), Assessment of procedures used for analyzing dietary fiber and some recent developments, Chemistry and Industry. 7: $225-230$.

Shils MEG, Young VR (1988). Modern Nutrition in Health and Disease. (Lea and Febiger, Philadelphia) 1988.

Starks M A, Starks S L, Kingsley M, Purpura M andJager R (2008). The effects of phosphatidylserine on endocrine response to moderate intensity exercise, $J$ Int Soc Sports Nutr. 5:11.

Spackman D H, Stein W H and Moore S (1958), Chromatography of amino acids on sulphonated polystyrene resins: An improved sustem, Anal Chem. 30: $1190-1205$.
Steinke F H, Prescher E E andHopkins D T (1980), Nutritional evaluation (PER) of isolated soybean protein and combinations of food proteins. J Food Sci. 45: $323-327$.

Sutchliffe J F and Baker DA (1974), Studies in Biology, No. 48 - Plants and Mineral Salts. (Edward Arnold Publishers Ltd., London ) 1974, pp. 11-25.

Tindall H D (1986), Vegetables in the Tropics. (ELBS/Macmillan, Houndmills)1986, pp. 247 - 248.

Tumbo P, Schlicker S, Yates A A and Poos M (2002), Food and Nutrition Board of the Institute of Medicine. The National Academies, J Am Diet Assoc. 102 (11): 1621-1630.

Wardlaw G M and Smith A M (2009), Contemporary Nutrition, 7th Ed. (McGraw-Hill International Edition, New York) 2009, pp. $120-600$.

Watkins B A and Seifert M F (1996). Importance of Vitamin $\mathrm{E}$ in Bone Formation and in Chrondrocyte Function. (Purdue University, Lafayette) 1996.

Whitney E N, Cataldo C B and Rolfes S R (1994), Understanding Normal and Clinical Nutrition. (West Publishing Company, New York) 1994, pp. 132 - 168; $880-909$.

WHO (2008), Interim Summary of Conclusion and Dietary Recommendations on Total Fat and Fatty Acids. From the Joint FAO/WHO Expert Consultation on Fats and Fatty Acids in Human Nutrition, 10-14 November, 2008. (WHO, Geneva) 2010, pp. 1-11.

Received: 12 April 2015; Revised: 10 May 2015; Accepted: 30 June 2015. 